\title{
PERCEPTIONS OF ELDERLY LIVING WITH LEG ULCER
}

\author{
PERCEPÇÕES DE IDOSOS VIVENDO COM ÚLCERAS DE PERNA
}

\section{Ana Luisa Zanardo BUSO ${ }^{1}$; Francielle Toniolo Nicodemos Furtado de MENDONÇA ${ }^{2}$; Judete Silva NUNES ${ }^{3}$; Lúcia Aparecida FERREIRA ${ }^{4}$; Álvaro da Silva SANTOS ${ }^{5}$; Fernanda Bonato ZUFFI ${ }^{6}$}

1. Enfermeira Especialista em Saúde do Idoso pela Residência Integrada Multiprofissional em Saúde - RIMS, Universidade Federal do Triângulo Mineiro - UFTM, Mestranda do Programa de Pós Graduação Stricto Sensu em Atenção à Saúde - PPGAS-UFTM, Uberaba, MG, Brasil; 2. Enfermeira Especialista em Saúde do Adulto - RIMS/UFTM, Uberaba, MG, Brasil; Mestre em Atenção à Saúde pela UFTM, Enfermeira de Saúde Pública da Secretaria Municipal de Saúde de Uberaba, MG, Brasil; 3 Enfermeira Especialista em Atenção Básica em Saúde da Família. Especialista em Gestão das Clínicas nas Regiões de Saúde. Especialista em UTI com ênfase em Urgência e Emergência.Tutora Presencial do Curso de Especialização em Atenção Básica em Saúde da Família pela UFMG/UFTM. Enfermeira da Secretaria Municipal de Saúde de Uberaba, MG, Uberaba, MG, Brasil; 4. Enfermeira, Doutoura em Enfermagem Psiquiatrica, Professora Adjunto IV no Curso de Graduação em Enfermagem da UFTM, Uberaba, MG, Brasil; 5. Enfermeiro, Doutor em Ciências

Sociais, Pós Doutorado em Serviço Social, Professor Adjunto IV no Curso de Graduação em Enfermagem e na PPGAS/UFTM,

Uberaba, MG, Brasil; 6. Enfermeira, Mestre em Enfermagem, Professora Assistente III do Curso de Graduação em Enfermagem da UFTM, Professora da RIMS/UFTM, Uberaba, MG, Brasil .

\begin{abstract}
This study aimed to describe the perception of the elderly about being a carrier of a chronic leg injury, accompanied by a Basic Health Unit of Uberaba, MG/Brazil. This is a descriptive research with a qualitative approach carried out through thematic analysis of content. They were assessed seven elderly patients with chronic ulcer of lower limb. Five categories emerged: Pain; Difficulties and/or dependence to perform the dressing; Image disorder; Inability to work; and Restriction for leisure. It observed the reality on the way of life of seniors with leg injuries, and we verified the importance to monitor them by a multidisciplinary team that supports the care aiming at the comprehensiveness of the human being.
\end{abstract}

KEYWORDS: Elderly. Leg ulcer. Nursing.

\section{INTRODUCTION}

Ulcers are defined as "any disruption in the solution of continuity of skin-mucosal tissue, causing changes in the anatomical structure or physiological function of the affected tissues" (BRASIL, 2002) and can receive some classifications, among which acute or chronic ulcers in accordance with the repair time, being named as the location and the pathophysiological process. The incidence and prevalence of chronic lesions should be considered, since they demand public and individual spending on care. We highlighted the Chronic Ulcers of Lower Limbs (CULL), which cause damage to the quality of life of individuals and reduce the ability to work, making it a public health problem (BRASIL, 2002; COSTA et al., 2012).

Among the CULL there are the vasculogenic, which are sub-classified etiologically in venous, arterial or mixed. They have a representation of $75 \%$ for the venous and of 10 to $25 \%$ for arterial and are related to poor perfusion of the lower limbs caused by disorders of the venous and/or arterial vascular systems. They are characterized by a chronic, painful and recurring process that requires multidisciplinary care with local and systemic interventions in order to minimize negative impacts on quality of life, on mobility, emotional state and functional capacity of people affected (ABBADE, 2011; ABREU; PITTA; MIRANDA JÚNIOR, 2012; CONUEI, 2009).

Chronic venous insufficiency is the result of valvular incompetence of the calf, and may be associated with an obstruction of venous flow. Arterial insufficiency is related to reduced blood flow in the artery due to often mechanical obstruction. These conditions can be evidenced in greater numbers in the elderly because they have aging as one of the predisposing factors, increasing the incidence of vasculogenic ulcers in the age group of 60 years or older. In addition, age is an important factor in healing, mainly due to conditions associated with senility as malnutrition, vascular insufficiency and systemic diseases. In the elderly, there is a reduction in the inflammatory response of the aged body, causing low metabolism of collagen, angiogenesis and epithelialization, increasing the healing time and facilitating recurrences (BRASIL, 2002; SILVA et al., 2009; GUYTON; HALL, 2011; BORGES; CALIRI, 2011; LIMA et al., 2011).

A study conducted in the University Hospital of Natal City sought to understand how patients with venous ulcers face this chronic disease 
evaluating their psychosocial adaptation. The results indicated that, regardless of age, carriers of such ulcers suffer from impacts related to pain, restrictions on leisure activities and married life, limitations at work and housework, walking difficulties, low self-esteem due to dissatisfaction with physical appearance, discrimination and dependency (COSTA et al., 2011).

Therefore, the occurrence of ulcers involves sudden changes in lifestyle due to the difficulties that need to be addressed in addition to the unpreparedness of patients and family members to deal with them effectively. Study identifies the need for adaptation, because of the impairment of mental, physical and social well-being (COSTA et al., 2011). The elderly population, due to cultural and inherent to aging issues, is less able to adapt to a new lifestyle. Thus, psychosocial and physical consequences can be even more severe in this population.

It is known that scientific knowledge, the correct clinical evaluation by a multidisciplinary team and the care with proper techniques by nursing staff are extremely important in the care of elderly people with chronic ulcer (BENEVIDES et al., 2012). However, we must know the perception of the elderly about their health and understand their main difficulty so that we can have information to adapt strategies to the elderly, by making the appropriate treatment in order to achieve improved quality of life.

In this sense, this study aimed to describe the perception of the elderly about being a carrier of a chronic leg injury, accompanied by a Basic Health Unit (BHU) of Uberaba, MG/Brazil.

\section{MATERIAL AND METHODS}

This was a descriptive research with a qualitative approach. This approach uses the experience and the view of the subject studied as data for production of knowledge through an emerging research model (POLIT; BECK, 2011).

The study was conducted in areas covered by three Family Health Teams (FHT) located in the Basic Health Unit (BHU) Dona Conceição Aparecida Ferreira in Uberaba - MG/Brazil. The study participants were seven people diagnosed with vasculogenic ulcers in the lower member identified by active search, which were residents of the coverage area and registered in one of the Family Health Strategies. All seniors with leg injuries identified during the data collection period agreed to participate in the study and signed the Informed Consent Form.
Data collection was carried out at home, from March to May 2014, following the ethical regulations. To preserve the identity, the elderly were named E1 to E7. The research was approved by the Research Ethics Committee of the Federal University of Triangulo Mineiro (CEP/CEUA) under protocol No. 2130 and was authorized by the Municipal Health Secretariat of Uberaba MG/Brazil.

To obtain the data, we used sociodemographic structured questionnaire to obtain the characteristics of the studied population and semi-structured interview in order to identify the perception of the elderly as carrier of leg ulcers. Numerical data were entered into the database in Microsoft Excel and analyzed through simple frequency. The interviews were recorded and transcribed to proceed data analysis.

The guiding questions of the interviews were: 1 - How is it for you to have a wound in the leg? 2- What are the main difficulties that the wound causes in your life? 3- What are the main difficulties related to wound care?

For analysis of the interviews, it used thematic analysis of content in order to "discover the meaning units that make up a communication whose presence or frequency mean something to the targeted analytical object" (MINAYO, 2014). For analysis of the interviews, it used thematic analysis of content in order to "discover the meaning units that make up a communication whose presence or frequency mean something to the targeted analytical object" (MINAYO, 2014). This analysis involves three steps: pre-analysis, exploration of the material and the processing of the results. Starting with the pre-analysis, they are made choices which will be analyzed in the study through the recovery assumptions and objectives proposed by the research. It involves fluctuating reading, intensive contact with the material, becoming impregnated by the content; Constitution of Corpus, through normative elements of qualitative validity: saturation of the material, representativeness of the desired universe, uniformity in the criteria for selecting the themes and relevance in achieving the goals. Finally, it includes the formulation and reformulation of hypotheses and objectives, if the author deems necessary (BARDIN, 2011).

The second stage of content thematic analysis is known for Material Exploration, which seeks to achieve understanding of core text by recording units, phrases or words that will base the organization of speech and information. Then the categorizations are performed and each category will represent a way of thinking describing a reality. 
Finally, treatment of the results and interpretation is the stage in which the raw data are subjected to simple statistical operations and then interpreted (BARDIN, 2011).

\section{RESULTS AND DISCUSSION}

Four women and three men were interviewed and the age ranged from 65 to 86 years old. As for marital status, $42.8 \%$ of the elderly were single and the others were widowed $(28,6 \%)$ and married (28,6\%). Regarding education, considering complete years of study, $42,8 \%$ were illiterate, $42,8 \%$ had between one and nine years of study and $14,3 \%$ had completed higher education. Only $14,3 \%$ of the elderly did not have monthly individual income and the others were retired, of whim $57,1 \%$ earned a minimum wage, $14,3 \%$ had an income of one to three minimum wages and $14,3 \%$ had income above three minimum wages.

On data obtained, there was a greater number of women with leg ulcer (57.1\%), corroborating the results found by several authors (COSTA et al., 2012; COSTA et al., 2011; BENEVIDES et al., 2012; DIAS et al., 2013; DIAS et al., 2014). This predominance in women may be associated with physiological changes that come with menopause, use of hormone replacement therapies and longevity, that is a female feature (BORGES; CALIRI, 2011).

In terms of age, all were older than 65 and the age group between 70 and 79 obtained the highest number of elderly (42.8\%). Studies on ulcer in lower limbs only the elderly are scarce. However, several authors who have researched populations with such pathology, regardless of age, identified prevalence in the population aged 60 years or more (BENEVIDES et al., 2012; DIAS et al., 2013; DIAS et al., 2014). The aging becomes a risk factor for the occurrence of CULL because the functional capacity and the body regulatory mechanisms are altered with the physiological processes of senescence. Furthermore, the elderly has increased reduction in healing capacity (BRASIL, 2002; GUYTON; HALL, 2011; BORGES; CALIRI, 2011; LIMA et al., 2011), which justifies the predominance of older age groups.

Unlike other studies, the predominant marital status in this study was single, with $42.8 \%$. In a study of elderly patients with leg ulcers in a dressing room of a specialized clinic in Fortaleza$\mathrm{CE}, 52.8 \%$ of the elderly were married or living in a stable relationship (BENEVIDES et al., 2012). Other studies addressing patients with CULL, regardless of age, also identified most married people or in a stable relationship, reinforcing the difference with the data obtained (COSTA et al., 2011; DIAS et al., 2013; DIAS et al., 2014).

Low education was prevalent among the elderly participants: $42.8 \%$ were illiterate and $28.6 \%$ had less than 5 years of study. These data corroborate research with people with CULL in which, regardless of age, level of education was found to be reduced (COSTA et al., 2011; BENEVIDES et al., 2012; DIAS et al., 2013; DIAS et al., 2014). Considering the population of this study, the low level of education may be associated with advanced age of the patients, since access to school in their youth was much lower than the present day.

Individual income of one minimum wage was the most present $(57.1 \%)$ among the elderly in this study. The result is similar to that found by research of people with venous ulcers, which had most of its population in the older age group, having incomes up to one minimum wage (BENEVIDES et al., 2012). Associated with the necessary care with leg injuries, low income can influence the shortage of material resources and poor access to health services, which are important for effective treatment.

After thematic analysis five themes emerged: Pain; Difficulties and/or dependence to perform the dressing; Image disorder; Inability to work; and Restriction for leisure.

Pain was reported as a frequent symptom among study participants.

[...]And when it hurts it, then I have to keep the foot up. Sometimes I prepare lunch with the foot up, it's horrible [...] I cannot go for a walk because it hurts too much. (E4)

The pain is the main difficulty for me. When my mother was alive I took care of her even with three wounds in the foot [...] I step on tiptoe with pain. (E6)

The wound hurts a lot. (E7)

According to the speeches, the pain may be associated with a great suffering for patients with a chronic injury leg. Consistent with this finding, studies conducted with people with CULL identified pain as a constant and very influential factor in the driving mode of treatment and in the quality of life of these individuals (BENEVIDES et al., 2012; DIAS et al., 2013; DIAS et al., 2014; LARA et al., 2011). 
Considering the population of this study and all the senile processes that involves it, it can be inferred that the presence of a painful injury associated with advanced age of patients generates excessive dependence on family/caregivers. Furthermore, the pain that starts with the formation of the lesion due to the pathophysiological process may persist after healing, becoming then a predictor factor of recurrence due to its chronicity (VANDENKERKHOF et al., 2013).

Elderly people who reported suffering with pain had difficulty on walking and on performing their activities autonomously. Therefore, they showed dissatisfaction and anguish with the way of life and because they know they will still live with the presence of pain for a long time. The pain in CULL has some distinctive features, such as worsening at night, causing sleep disturbances and severe disturbances in mobility, being a limiting factor for the activities of daily living (LARA et al., 2011). It is important that health teams consider the pain of these patients and develop strategies to minimize it, and that older people can maintain part of their activities and thus achieve better living conditions.

The second category, Difficulties and/or dependence to realization of the bandage was related to difficulty faced by the interviewed elders, once they cannot do the bandage by themselves or in an appropriate way or depending on a family member's help, caregiver or healthcare professional.

It is difficult to make the bandage, right? It has to be properly washed. (E1)

My son makes the dressing every day. I need him because I cannot do it alone. He also goes in the pharmacy or in the health unit to buy stuff for me. (E2)

[...] I have to stop the work to take care of it. There are times I need to do the dressing twice a day, I'm overworked and we do not have financial condition for it. (E3)

I find it very difficult to make the dressing, I do not do anything right. I had a black ointment I used to put since the last time, but it hurt a lot, and then stopped putting it. (E4)

Making the dressing is very difficult and I do not always have the material, right?! [...] When the ointment finishes, the injury gets worse. (E5)

At the time of washing and making the dressing, it also needs to be very carefully. (E6)
[...] I cannot do the dressing alone because it is far away, I cannot handle it. The M.J. does it when she can. (E7)

Chronic injury causes limitations on individuals, who become dependent of various activities and, regarding the healing, come to depend on qualified personnel to carry out it and adequate transportation for travel to locations where there is assistance for the care of the injury. In research with patients with CULL of different ages held in Minas Gerais, it was verified difficult to move the affected limb when they need to perform self-care (LARA et al., 2011).

It is also important to point out that the costs generated by the need for drug treatment and materials for dressing can generate a financial dependence both from family members as from the health system. These expenses, due to the chronicity of the injury, can destabilize the family financial situation (DIAS et al., 2013). Moreover, it generates overload in the public health system in which, according to another research, there is shortage of materials, lack of adequate infrastructure and trained professionals to provide good care for patients with venous ulcer (FIGUEIREDO; ZUFFI, 2012).

About body image, some elderly lines demonstrate dissatisfaction with the own appearance related mainly with the bandages; and that originated the category Image disorder. Dissatisfaction with the self-image can be considered a cause of social isolation.

[...] before I had my perfect leg, right? I have no desire to go into people's homes. I have a nephew who has two little girls and I do not like to go there, I am ashamed because they have gone to college. Some people see us like this and think we have no hygiene, no cleanliness and they become disgusted [...] then I think: going in the people's houses, what for? (E6)

People ask what I have when they see the bandage, this happens when I have courage and I leave home. (E1)

In this respect, study of patients with leg injury treated at an outpatient clinic of a polyclinic in Minas Gerais identified that respondents felt devalued, incapable and unstructured, by having to face great prejudice and social devaluation (LARA et al., 2011.

The elderly, as well as individuals from other age groups, seek to maintain their physical and mental integrity built throughout life, through coping strategies that provide a better quality of life. 
The body image is closely associated with quality of life, as it signals the balance or the internal imbalance of the individual to life in society, interfering with the formation of their social identity (PEREIRA-JUNIOR; HENRIQUE, 2010).

Regarding the category Inability to work, the following lines stand out:

Without the wound I used to put the boot that I need, without the boot it makes me sick and I cannot work. (E3)

I cannot work, I do cookies to sell. (E4)

I cannot do many things, such as working, going where I want and when I go, it is a hard task. (E5)

(...) I spend most of the time lying on the couch under the covers, no mood for anything. (E6)

This wound does not let me do all my things, taking care of the house. (E7)

The elderly reported that they fail to develop activities that help their families generating extra income, as well as housework. A study that used the Roy Adaptation Model to classify changes in the lives of patients with venous ulcers identified that there is a reduction in family income and production at work. In addition, they start to have trouble in getting employment opportunities and it is not possible to do activities that are pleasurable. Corroborating the findings, this study also found that individuals are dependent for carrying out household activities, due to suffering with pain (COSTA et al., 2011).

Failure to develop such activities can generate feelings of frustration and uselessness for the elderly. They start to feel like an "extra burden" to their caregivers, whether they are family members or not. Added to this, there is the fact that they live in idle mode, without interaction with society and with activities that can occupy their mind and keep them active.

The last category of this study, Restriction for leisure, was composed by reports of elderly people that showed, due to the consequences of the injury, these moved away from leisure activities once performed frequently.

My greatest joy is to dance forró on Sundays and now I cannot go, it hurts a lot. (E7)

I cannot go hiking because it hurts a lot, I cannot do physical activities also. (E4)

[...] I have no more strength in the leg, I walk with difficulty and I cannot do anything without the cane. I cannot even sweep the street [...] I used to talk to everyone in the street when I went to sweep. (E5)

I'm afraid of falling because I walk with difficulty, I need to get up carefully and therefore I spend most of the time lied down. I no longer go out from home. (E6)

With this study, we identified that the consequences that reach individuals with CULL are interdependent: pain, image disorder and dependency on others. However, it is important that individuals with chronic ulcers have coping strategies of the disease that increase selfconfidence and hope in treatment. Leisure activities can contribute by occupying the time and thought. And for that, the support of family and friends is critical, minimizing psychosocial effects (LARA et al., 2011).

The pain, symptom present among them, is a source of suffering and distress in their lives. Realized that the need for help for failing to perform the dressing alone is a great difficulty and generates constant dependence. In addition, the elderly have shown that body image changed is social isolation factor which may influence the quality of life and that the work and leisure activities are greatly affected by the presence of the lesion causing frustration and causing this elderly feel useless in the family and society.

It is noticeable that all the categories that emerged from the speeches of the elderly are related to each other and are responsible for causing profound consequences in the way of life of these individuals. Therefore, it is important that older people with CULL are accompanied by a multidisciplinary team to conduct a work focused on the comprehensiveness of the human being. It is known that the proper functioning of the body requires care from different areas, and the lack of any of them can become an aggravating factor of health problems.

All symptoms and the entire representativeness of a leg injury to an elderly must be considered in their treatment. Pain control and the development of strategies to deal with it are of utmost importance to improve the quality of life of these individuals. Educating the family about the importance of proper care and the involvement of the injured individual with simple activities can be an alternative so there are fewer feelings of social devaluation and worthlessness. It is necessary to strengthen self-care, even if it is done to a lesser extent.

Also, encouraging the participation of the elderly in community activities is a social 
engagement strategy to reduce the psychosocial consequences that the injury can cause. Associated with this, there is the importance of enhancement of self-esteem and the performance of dressings by a qualified nursing staff in order to reduce possible discomfort related to body image.
Given the discomfort that a wound can generate in the aged one, if it more becomes important that other qualitative and also quantitative studies can better delineate this phenomenon, with sights the action directed the reality of being aged with leg wound.

RESUMO: Este estudo teve como objetivo descrever a percepção do idoso acerca de ser portador de lesão crônica de perna, acompanhados por uma Unidade Básica de Saúde de Uberaba, MG/Brazil. Esta é uma pesquisa descritiva com abordagem qualitativa realizada através de Análise Temática de Conteúdo. Foram avaliados sete idosos portadores de úlcera crônica de membro inferior. Emergiram cinco categorias: Dor; Dificuldades e/ou dependência para realização do curativo; Distúrbio de imagem; Impossibilidade para o trabalho; e, Restrição para o lazer. Verificou-se a realidade vivenciada por esses idosos com lesões de perna, sendo importante o acompanhamento destes por uma equipe multiprofissional que apoie o cuidado visando à integralidade do ser humano.

PALAVRAS-CHAVE: Idoso. Úlcera da perna. Enfermagem.

\section{REFERENCES}

ABBADE, L. P. F. Diagnósticos diferenciais de úlceras crônicas dos membros inferiores. In: MALAGUTTI, W., KAKIHARA, C. T. Curativo, Estomia e Dermatologia: uma abordagem multiprofissional. São Paulo: Martinari, 2011. p. 73-88.

ABREU, J. A. C.; PITTA, G. B. B.; MIRANDA JÚNIOR, F. Avaliação do segmento femoropoplíteo pela ultrassonografia Doppler em pacientes com úlcera varicosa. J Vasc Bras. v. 11, n. 4, p. 277-83, 2012. Disponível em: http://www.scielo.br/pdf/jvb/v11n4/05.pdf. Acesso em: 20 jun. 2014.

BARDIN, L. Análise de conteúdo. São Paulo: Edições 70, 2011, 229 p.

BENEVIDES, J. P.; COUTINHO, J. F. V.; SANTOS, M. C. L.; OLIVEIRA, M. J. A.; VASCONCELOS, F. F. Avaliação clínica de úlceras de pernas em idosos. Rev Rene. v. 13, n. 2, p. 300-8, 2012. Disponível em: http://www.revistarene.ufc.br/revista/index.php/revista/article/view/213/pdf. Acesso em: 20 jun. 2014.

BORGES, E. L.; CALIRI, M. H. L. Funcionamento do sistema venoso. In: Feridas: úlceras dos membros inferiores. Rio de Janeiro: Guanabara Koogan, 2011. p. 3-9

BRASIL. Ministério da Saúde. Secretaria de Políticas de Saúde. Departamento de Atenção Básica. Manual de condutas para úlceras neutróficas e traumáticas. Ministério da Saúde. Secretaria de Políticas de Saúde. Departamento de Atenção Básica. Brasília: Ministério da Saúde, 2002. 55 p.

CONFERÊNCIA Nacional de Consenso sobre Úlceras de la Extremidad Inferior. Documento de Consenso C.O.N.U.E.I. Barcelona: Kamed; 2009.

COSTA, I. K. F.; NÓBREGA, W. G.; COSTA, I. K. F.; TORRES, G. V.; LIRA, A. L. B. C.; TOURINHO F. S. V.; ENDERS, B.C. Pessoas com úlceras venosas: estudo do modo psicossocial do Modelo Adaptativo de Roy. Rev Gaúcha Enferm., Porto Alegre, v. 32, n. 3, p. 561-8, 2011.Disponível em: http://www.scielo.br/pdf/rgenf/v32n3/18.pdf. Acesso em 23 jun. 2014.

COSTA, L. M.; HIGINO, W. J. F.; LEAL, F. J.; COUTO, R. C. Perfil clínico e sociodemográfico dos portadores de doença venosa crônica em centros de saúde de Maceió (AL). J Vas Bras. v. 11, n. 2, p. 108-13, 2012. Disponível em: http://www.scielo.br/pdf/jvb/v11n2/v11n2a07.pdf. Acesso em 23 jun. 2014. 
DIAS, T. Y.; COSTA, I. K.; SALVETTI, M. G.; MENDES, C. K.; TORRES, G. V. Influência da assistência e características clínicas na qualidade de vida de portadores de úlcera venosa. Acta Paul Enferm., v. 26, n. 6, p:529-34, 2013. Disponível em: http://www.scielo.br/pdf/ape/v26n6/04.pdf. Acesso em 28 jun. 2014.

DIAS, T. Y. A. F.; COSTA, I. K.F.; MELO, M. D. M; TORRES, S.M.S.G.S.O; MAIA, E. M. C; TORRES, G. V. Avaliação da qualidade de vida de pacientes com e sem úlcera venosa. Rev. Latino-Am Enferm.v. 22, n. 4, p. 576-81, 2014. Disponível em: http://www.scielo.br/pdf/rlae/v22n4/pt_0104-1169-rlae-22-04-00576.pdf. Acesso em: 22 set. 2014.

FIGUEIREDO, M. L.; ZUFFI, F. B. Atención a pacientes con úlcera venosa: percepción de los enfermeros de Estrategia de Salud Familiar. Enfermería Global [periódico na internet]. 2012; v. 11, n. 4, p.147-58, 2012. Disponível em: http://scielo.isciii.es/pdf/eg/v11n28/docencia4.pdf. Acesso em: 29 jul. 2014.

GUYTON, A. C.; HALL, J. E. Distensibilidade Vascular e Funções do Sistema Arterial Venoso. In: Tratado de Fisiologia Médica. 11ed. Ed. Elsevier Brasil, Rio de Janeiro, 2011. p. 177-81.

LARA, M. O.; PEREIRA JÚNIOR, A. C.; PINTO, J. S. F.; VIEIRA, N. F.; WICHR, P. Significado da ferida para portadores de úlceras crônicas. Cogitare Enferm., v. 16, n. 3, p. 471-7, 2011. Disponível em: http://ojs.c3sl.ufpr.br/ojs/index.php/cogitare/article/viewFile/20178/16232. Acesso em: 29 jul. 2014.

LIMA, M. P.; LIMA, V. L. A. N; CARVALHO, D. V; BORGES, E. L. Insuficiência arterial. In: Feridas: úlceras dos membros inferiores. Rio de Janeiro: Guanabara Koogan, 2011. p. 97-108.

MINAYO, M. C. S. Técnicas de Análise do Material Qualitativo. In: O Desafio do Conhecimento: Pesquisa Qualitativa em Saúde. 14.ed. São Paulo: Hucitec Editora; 2014. p. 316.

PEREIRA-JÚNIOR, A. D. C.; HENRIQUES, B. D. The nursing care of the colostomy patient. J. of Nursing UFPE [Online]. v. 4, n. 3, p. 990-5, 2010. Disponível em: http://www.revista.ufpe.br/revistaenfermagem/index.php/revista/article/viewArticle/751. Acesso em: 29 jul. 2014.

POLIT, D. F, BECK, C. T. Delineamento e abordagens de pesquisas qualitativas. In: Fundamentos de Pesquisa em Enfermagem 7.ed. São Paulo: Artimed; 2011. p. 288-315.

SILVA. F. A. A.; FREITAS, C. H. A.; JORGE, M. S. B.; MOREIRA, T. M. M.; ALCÂNTRA, M. C. M. Enfermagem em Estomaterapia: cuidados clínicos ao portador de úlcera venosa. Rev Bras Enferm. Brasília, v. 62, n. 6, p. 889-93, nov-dez 2009. Disponível em: http://www.scielo.br/pdf/reben/v62n6/a14v62n6.pdf. Acesso em: 20 jun. 2014.

VANDENKERKHOF, E. G.; HOPMAN, W. M.; CARLEY, M. E.; KUHNKE, J. L.; HARRISON, M. B. Leg ulcer nursing care in the community: a prospective cohort study of the symptom of pain. BMC Nursing. v. 12, n. 3, 2013. Disponível em: http://www.biomedcentral.com/content/pdf/1472-6955-12-3.pdf. Acesso em: 20 jun. 2014. 